\title{
Politologia
}

\section{The cartel party, consensus democracy and democracy without politics ${ }^{1}$}

\author{
Richard S. Katz
}

The Johns Hopkins University

\section{Abstract}

Although the age of the mass party as an organizational form is long in the past, the mass party remains a widely accepted normative ideal, closely connected to the idea of party government and to a voters-as-principals-parties-as-agents understanding of democracy. In evolving from mass party, to catch-all party, to cartel party European democracies have also been evolving towards an 'anti-political' view of government, along with models of consensus democracy and the regulatory state. This evolution helps to explain the decline in popular connection to political parties. Ironically, the associated causes of this decline are generally regarded as good, notwithstanding that the decline itself is often identified as a crisis. Moreover, analysis of this decline suggests as striking similarity between the consensus model of democracy and the cartel party model of democracy, notwithstanding that the first is often seen as a goal to which democracies should be moving while the second is seen as a threat to democracy itself.

\section{Key words}

cartel party, party models, democratic crisis, consensus democracy

The idea of the cartel party arose inductively from an attempt to
understand the data collected by Peter Mair and me, along with an
extensive team of collaborators, on party organizations and organiza-
tional change in Western Europe. The time periods examined differed
slightly depending on the research choices made by those working on
each country, but generally covered either $1960-1990$ or $1945-1990$.

1 Significant portions of the lecture given in Warsaw, on which this article is based, were drawn from Blyth and Katz (2005), and from Katz (2013). 
However, the implicit starting point for the whole project was the model of the mass party.

When we began our work, it was already widely recognized that the 'mass party' in its pure form was becoming, if it had not already become, a relic of the past. After all, Otto Kirchheimer (1966) had published his famous article on the 'catch-all party' more than two decades earlier. But the mass party model of a party as an organization rooted in and reflecting social cleavages, supported and controlled by a grassroots membership, separate from the state, and engaged in zero-sum competition with other, organizationally similar, parties over both policies and offices clearly remained the standard against which parties were judged. Failure to live up to this ideal defined the idea of party failure (e.g. Schmitter, 2001). Even today the mass party model remains extremely powerful as a normative standard in much of the literature on political parties, whatever its empirical standing may be (e.g. OSCE/ODIHR, 2011). In our original article on the cartel party (Katz and Mair, 1995), we associated each of the four party models we discussed (elite party, mass party, catch-all party and cartel party) with a particular understanding of democracy. My aim in this article is to return to that basic theme, but from a different perspective.

This article proceeds in five basic steps. Firstly, it addresses what I think is still the dominant theoretical understanding of the way parliamentary democracies work. This may be identified as 'democratic party government', but notwithstanding the fact that Arend Lijphart might object, I also argue that it includes what he identified as 'majoritarian democracy' (Lijphart, 1999: 2-30).

Secondly, the majoritarian model is compared and contrasted with what has become an increasingly popular view of what democratic governance should be like - the complex of consensus democracy, the modern regulatory state, a corporate governance style, postpartisanship, and perhaps deliberative democracy and the politics of presence as well. It is posited that in a fundamental sense this is not an alternative but an equivalent form of democracy, but rather that it is a lesser democracy, even if it might be better government (this question is not addressed in this article). 
Thirdly, I argue that the evolution of party politics since the era of the mass party in the early part of the 2oth century has been accompanied by a parallel evolution in the way of thinking about government, democracy and society in general, towards an 'anti-political' view. In using the word 'parallel' I do not mean to suggest a direct causation, either one way or the other.

Fourthly, I suggest that many of the problems commonly identified as 'crises' in modern European democracies - most especially the declining participation in electoral politics - can be understood as natural consequences of processes that are otherwise considered to be good. Prominent among these processes is precisely the promotion of consensus democracy and models of good - but not partisan governance.

Finally, the article returns to the cartel party and suggests that there is a striking similarity between the consensus model of democracy and the cartel party model of democracy, even though the former is frequently regarded as goal toward which societies should be moving, while the latter is generally regarded as a pathology.

To begin with, the model of party government or majoritarian democracy, or a simple principal-agent understanding of democracy, is composed of three major elements. First, parties act as the agents of national groups of voters in making and implementing policy. Party names are, in a sense, simply identifiers of bundles of policies that they promise to put into effect. Second, and corresponding to the idea that party names are labels for policy packages the groups of voters who are the principals in this principal-agent situation are defined by their policy preferences. And it is this relationship - between groups of voters as principals who want particular policies put into place and parties as their agents in making that happen - that defines the representation aspect of parliamentary representative government. Third, elections are the institutional device through which the principal-agent relationship between voters and governors is established and enforced. Further, effective representation means that there is a close correspondence between the policy positions acted upon or articulated by the party 
elite (MPs, MEPs, cabinet ministers) and the policy preferences of the masses (either party members or voters), and perhaps even more strongly that the policy preferences of the 'median MP' are close to those of the 'median voter'. All of this allows representative government to be a reasonable approximation of democracy, because it means that the parties are doing what the citizens would have done in their own persons had direct democracy been possible. Hence we arrive at a definition like that of Arend Lijphart, who defines democracy in the 'the most basic and literal' way as 'government by the people or, in representative democracy, government by the representatives of the people' (Lijphart, 1999: 1).

If we understand representation in this narrow sense of the policy-correspondence coupled with the parties-as-reliable-policy-agents model, then on one hand Lijphart's 'most basic and literal' definition says something of real substance, while on the other hand he cannot actually mean it. Alternatively, if we understand the issue of representation much more broadly, as it seems we must do if we are to accept Lijphart's consensus democracy as actually being democratic, then the definition really says very little.

So what can be said about representation as postulated by Lijphart? Representation is relatively unproblematic in Lijphart's majoritarian model - at least if one accepts his implicit assumption of a completely unproblematic principal-agent relationship between voters and parties. Basically, majoritarian democracy is two-block, policy-oriented, party government. The representatives are parliamentary Fraktionen. The form of representation is delegation - the parties do what their supporters want. The standard for measuring the success of the representativeness of the parliament is whether the party with a majority of the votes (which means that its policies are supported by a majority of the citizens) has effective control of the parliament, and thus of the government.

Turning once again to Lijphart's consensus model, we can say three important things about representation, all of which dilute the simple party-as-agent-voters-as-principals sense of representation. First, if - as Lijphart says - 'negotiation democracy' is to be a synonym for consensus 
democracy (1999: 2), then the representatives must be able to negotiate, but this implies a freedom of action far more consonant with a trustee than with a delegate role orientation - the plena potestas of medieval English MPs rather than the imperative mandate of the mass party.

Second, strong and independent central banks, strong and independent constitutional courts, strong neo-corporatist institutions all are among the defining characteristics of consensus democracy. If Lijphart's 'most basic and literal' definition of democracy is to be maintained, then these institutions must somehow be judged to be 'representatives of the people'. Even more than with parties negotiating in parliament, these must also assume a trusteeship understanding of representation. Particularly with respect to courts and central banks, the very definition of 'independence' means that they are isolated from any direct political connection to the people.

It seems inescapable that the only way to reconcile independence in this sense with representation is to equate acting in one's professional assessment of the interests of the people with being a representative of the people. This obviously is a big stretch. An analogous stretch, in the terms of principal-agent models, would be to identify parties as the agents of the public simply because they are pursuing their conception of what is in the public's interest. Even more, this argument would lead to the identification of benevolent dictatorship as a form of representative democracy, because the dictator is pursuing his/her own conception of the public's interest. It would also be analogous to identifying a good parent as the agent of the child because the parent is trying to bring the child up according to the parent's understanding of what is in the child's best interests. Clearly we regard this kind of parenting as a good thing but we still recognize that no matter how much gender equality we have between the father and the mother, a family is not, and should not be, a democracy between the parents and the young children. I emphasize all this because the alternative to regarding these non-accountable actors as representatives of the people would be giving substantial power to agencies that are NOT representatives of the people - and within Lijphart's 'most basic definition' that seems 
inevitably to make consensus democracy a lesser democracy rather than simply an alternative structuring of democracy.

In general terms, the above reasoning suggests two important ways in which the consensus model of democracy is incompatible with the conventional principal-agent model of representation. The first is the possibility that there are representatives other than party Fraktionen, and the second results from the heavy emphasis placed on trusteeship rather than delegation as the mode of representation.

The emphasis on trusteeship in turn raises two sets of questions. First, how does a trustee differ from a benevolent (or perhaps even a not-so-benevolent) dictator? And how do we assure that a benevolent dictator will remain benevolent? Obviously, the conventional answer would be through periodic elections, but this certainly will not work - indeed the situation is intentionally set up to prevent it from working - in the case of independent courts and independent central banks, and one could say the same of neo-corporatist institutions as well. Moreover, what happens if the parties contesting the elections do not raise the questions about which voters care, or do not differ with respect to them. The possibility of voting Tweedledee out of office is not much help if the only alternative is Tweedledum - or Tweedledumber.

Second, what does trusteeship mean? What does a trustee do? Evidently for Lijphart, the answer is that she produces 'good government'. The definition of 'good' is provided by Lijphart in the standards by which he compares majoritarian and consensus democracy: economic growth; low unemployment; low inflation; few strikes and public disruptions; an egalitarian distribution of income and wealth; popular satisfaction; more women in parliament etc. Aside from the fact that not all of these 'good' features are self-evidently good, we end up with justification or legitimation on the basis of outputs, i.e. a technocratic or managerial standard of the public good.

I raise this critique because this kind of preference for the consensual model of democracy, and for technocratic legitimation of the political system, is very much in evidence in modern political discourse, and in particular in the evolution of the European Union. 
Lijphart would like to cast the distinction between majoritarian and consensus democracy as a contrast between - on the one hand - the view expressed by Irish humourist Leonard Wibberly in The Mouse That Roared that 'no nation can be governed well unless there is a majority that can impose its will upon a minority' (Wibberly, 1955: 11), and on the other hand the view that compromise and accommodation are superior ways of reaching collective decisions. An alternative, however, would be to cast majoritarian democracy as the making of collective decisions in cases of conflicts of interest, and consensus democracy as the peaceful and equitable management of a society in the common interest, about which there is no serious or fundamental conflict.

Here two observations should be highlighted. First, one should not overlook the emphasis on management in this second characterization of consensus democracy. Second, and more importantly - if what distinguishes politics is, as Sam Finer argues, '(1) that a given set of persons require a common policy; and (2) that its members advocate, for this common status, policies which are mutually exclusive' (Finer, 1970: 8), then the reasoning underlying consensus democracy largely reads the politics out of democracy.

Without developing the point here beyond a quick summary, it can be observed that the evolution of the series of democratic theories, i.e. the mass party, the catch-all party, and lastly the cartel party, has been in the direction of this de-conflictualization, and therefore fundamentally toward the de-politicization of democracy. Politics as conflict, and parties as agents, are fundamental to the democratic theory of the mass party. The replacement of the mass party by the catch-all party as the dominant form of party organization was accompanied by a shift, or perhaps more accurately a schizoid bifurcation, in the dominant understanding of parties and their proper role in democratic societies. While the ideas of parties as agents of society, and as organizations that should be directed by their base members, continued to play a significant role in political discourse and in some scholarly analyses, including in particular parts of the rational choice literature, nevertheless at the same time this principal-agent understanding of the role of parties has been undercut by 
the pluralist idea of parties as brokers among various interests (Truman, 1951; Dahl, 1956), and by the idea that continuous compromise in order to find the 'middle ground' is better than one side winning and the other losing, even if over the long term they will alternate in office. This idea of democratic politics gives parties a far more directive role than mere 'agency' would suggest. Indeed, as Dahl (1961: 6) says, 'a leader who knows how to use his resources to the maximum is not so much the agent of others as others are his agents'.

The democratic theory of the cartel party is, in a sense, an extension of both the pluralist and liberal elitist theories. Democracy is synonymous with the capacity of voters to choose among a menu of political parties. Parties are alliances of professionals, not associations of citizens, and voters do and should choose between them on the basis of their 'qualifications' and management skills rather than policy proposals.

'Synonymous', however, is a far stronger word than 'required' (as in 'elections are required for democracy'), particularly because of what it leaves out. The older models of democracy assumed that the possibility of being voted out of office would provide a powerful incentive for politicians to be responsive to the desires of citizens. A key element of cartelization, however, is to obscure the distinction between the 'ins' and the 'outs', and by reducing the costs of being 'out' to reduce the power of the electoral incentive. And one should recall here that this lack of difference, in terms of the winners' and losers' satisfaction (what difference does it make who wins?) is - according to Lijphart - one of the 'good' features of consensus democracy.

Democracy is transformed from a process by which the state is controlled by civil society into a service that is provided by the government, much as the state provides physical security through its police forces. But since democracy requires elections among political parties, according to this understanding the state assumes responsibility for providing - or at least guaranteeing the provision of - not only elections but political parties as well. 
The electoral process performs a number of functions that are valuable for the state. Parties and elections provide for the peaceful renewal of political/governmental leadership. Even if the direct consequences for policy (or even for the well-being of individual politicians) are minimal, elections provide feedback to the government (analogous to what might be obtained through a sample survey or a focus group study) regarding general levels of popular satisfaction. While the form of electoral competition remains, in substance it becomes competition about managerial competence rather than alternative policies, which in effect makes all potentially governing parties mouthpieces for and defenders of the policies of the state. As Sir Humphrey Appleby, the fictional cabinet secretary of Antony Jay's and Jonathan Lynn's British sit-com Yes, Prime Minister, succinctly puts it: 'We run a civilized, aristocratic government machine, tempered by occasional general elections. Since 1832 we have been gradually excluding the voter from government. Now we've got them to a point where they just vote once every five years for which bunch of buffoons will try to interfere with our policies'. But put in these terms, parties collectively become agents of the state, performing a variety of services for the state in exchange for financial support (direct financial subventions both to the parties' central offices and to the parties in public office, provision in kind of media time, etc.).

The summary above can be seen as contrasting two opposing principal-agent accounts of party politics. One might be described as the normative democratic theory account. In this version, the voters are the ultimate principal, with parties (particularly the party in public office, hired and fired through elections) as their agents. Simultaneously, the parties on the ground are seen as principals, with the party in public office as their agent. Given the conflicting pressures put on the party in public office by having two principals making potentially conflicting demands, the party on the ground also hires a party central office as its agent to supervise the party in public office. As a second step in this chain, the base of the party in public office (for convenience, the 'parliamentary party') establishes a leadership cadre (ministers and potential ministers) as its agent. Finally, the party in public office, through the agency 
of the ministry, employs the state (i.e. the bureaucracy) to implement its (ultimately 'the public's') policies and to do the actual work of governing.

In the alternative, realpolitik, account, all of this is reversed. To very loosely paraphrase Richard Crossman's Diaries of a Cabinet Minister, the bureaucracy employs ministers as their agents to defend the department's budget, to argue for the department's policies in cabinet, and to steer the department's legislation through parliament (Crossman, 1976). Ministers act as principals who hire the parliamentary party to support them - using the possibility of promotion and perhaps some policy influence as the payoff. We can see a particularly overt example of this in the May 2005 vote of confidence in the Paul Martin government in Canada, in which one MP essentially offered his support for sale the price being more aid for Darfur. But it is also inevitably reflected in any negotiations over the formation of a coalition in which the formateur effectively buys the support of potential coalition partners with some combination of offices and policy payoffs. Collectively, the party in public office hires a party central office to help them in organizing and controlling the party on the ground in order to mount electoral campaigns, which are effectively about the party as principal hiring voters as agents to support them at the polls.

While it is clear that each of the relationships discussed above can be understood as involving some kind of exchange, it is not clear at all who (if anyone) in these exchanges should be regarded as a principal and who should be regarded as an agent. In simple terms, and looking only at one end of the chain, it may be asked whether parties hire voters using a variety of solidarity and private material incentives to induce them to act for them in campaigns (e.g. Panebianco, 1988), or whether voters hire party leaders to govern for them in exchange for the private rewards of office (e.g. Downs, 1957).

If we accept the principal-agent party-government model of democracy - keeping in mind that I have just argued above that there are good reasons why we should not - then we can identify a number of trends in contemporary European politics that should give us pause. Here I identify three aspects of this process. The first is the popular disengagement from 
party politics: declining turnout; declining party membership; and declining interest in politics as a spectator sport. A second aspect is the lessening of the substantive significance of those questions that are the subjects of partisan debate, no matter how intense the competition and acrimonious the debate may be. This is exemplified, for example, in the commonly expressed view that, immediately after Silvio Berlusconi defeated Walter Veltroni at the polls in the 2008 Italian election, the two should start working together as a team. The third aspect is the removal of important questions from the sphere of decision-making by partisan, electorally accountable, officials, i.e. in terms of European democracies, by cabinets and parliaments. Although some reference will be made to the second and third of these aspects, the primary focus here is on the first, that is the weakening of popular involvement with party politics.

The first step in trying to understand the disengagement of citizens from parties is to ask why people would become involved in party politics in the first place. This is obviously a very complex question, to which six possible and theoretical answers are offered here. While these are presented with specific reference to electoral turnout, the same general argument should apply, mutatis mutandis, to other areas of partisan activity or involvement (for an elaboration of these ideas with respect to party membership, see Katz, 2013).

The first might be called the 'simple Downsian' answer, based on the classic rational choice model. Individual citizens are trying to maximize their satisfaction while minimizing their costs. In terms specifically of voting, each citizen assesses his/her expected utility under each possible outcome of an election, discounts the differences in expected utilities by the probability that his/her vote will bring about one outcome rather than another, and votes or abstains so as to maximize his/ her expected utility (Downs, 1957:36-50). If the differences in outcomes shrink, then so will the probability of voting.

The second theoretical answer might be called the 'subjective Downsian' answer. As is well known (although the rational choice theorists do not often want to admit it), it is never rational to vote within the strict terms of their model. In the subjective Downsian model, the key variables 
would not be real expected utilities and real probabilities of making a difference, but rather perceived expected utilities and perceived probabilities. The voter makes the same calculations as in the simple Downsian model, but the 'numbers' that go into those calculations may be wrong. The problem from the rational choice perspective is that while this model retains the individualism of the rational choice paradigm, it shifts the center of attention from the rational processing of information to the non-rational development of potentially, or even certainly, inaccurate beliefs. But as with the simple Downsian answer, if the perceived differences in outcomes shrink, then so will the probability of voting.

The third possible answer is 'social Downsian'. This model retains the assumption that perceived utilities and probabilities are directly grounded in reality, but replaces the individualism of the simple model with an orientation toward groups. In this case, the key variable is not the probability that one citizen's vote will make a difference, but rather the probability that the votes of the group to which the citizen understands himself/herself to belong will make a difference - and this probability will often be great enough to make voting rational. But yet again this depends on the magnitude of the differences in outcomes, as well as on the strength of group identification.

The fourth possible answer is based on 'opinion voting', according to which voting, instead of being instrumental, is expressive. The assumption here is that the citizen is voting to express support for or opposition to - the policy proposal(s) associated with a particular political party.

Fifth, there is what Parisi and Pasquino (1979) called the voto dappartenenza or the vote of identification. In this case, the voter is expressing his/her solidarity directly with a party, or with a group (e.g. a confessional group, ethnic group, or social class) that is associated with the party. As with opinion voting, the probability that his/her vote will make a difference to the electoral outcome does not enter into the calculation, although the strength of his/her group identification is clearly crucial. 
The sixth possible answer is 'obligatory voting. The citizen votes simply because he/she thinks he/she should. While this sense of obligation could be increased by making voting legally compulsory, this is primarily about a sense of felt obligation rather than a simple legal requirement, and might well extend into areas of engagement that are not subject to legal regulation ${ }^{2}$.

Finally, we can add to the above the important observation that whatever the objective of the citizen for getting involved in partisan politics, the level of involvement will also be influenced by the availability of alternative ways of achieving the same ends.

If some combination of these theoretical models explains why people become involved in party politics, what then explains why fewer and fewer people do so? I think we can suggest four basic answers to this question. The irony is that while the resulting disengagement is generally regarded as bad - as a problem or a threat, or even in more alarmist renderings a crisis ${ }^{3}$ in need of amelioration - each of these answers, i.e. likely causes, is generally regarded as good.

The first of is the breakdown of the rigid social divisions that was taking place throughout the 2oth century, but which progressed most rapidly over the last 50 years or so. This process has been evident in many dimensions. One is the obvious secularization of modern societies. To take an example from a country that generally served as the archetype of a segmented society, between 1967 and 1986 the percentage of the Dutch population identifying themselves with the Dutch Reformed Church fell by half, from 30 to 15 percent. While the percentage identifying themselves as Catholic only declined from

2 In the guise of a 'citizen's duty'. This is sometimes combined with the simple Downsian model in order to finesse the irrationality of voting: citizen duty makes it rational to vote, while simple Downsian calculations determine the party given support.

3 For example, in writing about the low turnout in the 2001 British general election then the lowest (by more than ten percent) since 1945 - Whiteley et al. (2001: 786) observed that 'the word crisis is often abused in contemporary accounts of politics. But if this is not a crisis of democratic politics in Britain, then it is hard to know what would be'. 
37 to 31 percent, the percentage of Catholics attending church at least once a week plunged from 75 to 26 percent. Perhaps of even greater significance has been the erosion of class divisions across Europe. This is evident both in increased inter-generational mobility, and in the greater similarity of life-styles and life-chances across what were once much more rigid class divisions. Accompanying these trends there has been tremendous growth in the proportion of the population identifying themselves as 'middle class'. For example, in 1963 Butler and Stokes (1969: 67) found that 32 percent of the British identified themselves as 'upper middle', 'middle', or 'lower middle' class; but in the 1995 wave of the World Values Survey in Britain 68.8 percent identified themselves as 'upper middle' or 'lower middle' class.

It is difficult to argue with the view that the resulting lessening of interclass and inter-confessional hostility is a good thing. It is certainly what the model of consensus democracy, and indeed any model that privileges a common interest or social solidarity, must approve. At the same time, it is widely recognized that these developments also undercut the social basis of the mass party of integration - a party model typified by the politics of mobilization. Thus it should hardly be surprising that one result of the decline in mobilization as a dominant political strategy is that fewer citizens are in fact mobilized.

More specifically, insofar as class and religious prejudices are generally regarded as bad, the weakening of these divisions should be expected to have a direct negative impact on both social Downsian voting and on the voto d'appartenenza. In addition, by indirectly encouraging parties to moderate their positions or converge toward the median voter, these trends should be expected to reduce simple and subjective Downsian voting as well. The increased cognitive mobilization, economic prosperity, and leisure time that have accompanied these trends should have a negative impact on voting by broadening the range of alternatives open to citizens.

The second general explanation stems from the increasing tendency for the political debate to revolve around questions of competence and efficiency rather than ideology. Government in general, and the rule 
of a specific party or coalition in particular, is legitimated by the (economic) quality of its outputs rather than by the (democratic) quality of its inputs or processes. Decisions in many fields are delegated to bodies that are not directly accountable at the ballot box, and justified or evaluated with reference to professional and technocratic standards. With regard to elected officials, attention is increasingly focused on questions of personal (and relatively petty) honesty and virtue (using a government credit card for private purchases, even if the bill is paid by private funds; using air miles accumulated on government travel for private holidays - which is done all the time in the private sector), rather than on ideas and values.

Again, it is hard to argue against efficiency or honesty, but at the same time they undercut many of the incentives for citizen involvement in partisan politics. The emphasis placed on questions of technique rather than questions of preference marginalizes citizens from political decisions, and privileges the experts. Not only are the policy stakes of electoral competition lowered, but in addition the emphasis on bureaucratic neutrality and personal honesty reduces the value of patronage and other individual or group-oriented selective incentives for partisan involvement.

The third general explanation is closely related to what has been said above. It is the increasing acceptance of the model of consensus democracy (Lijphart, 1999), and the values that underlie it, as superior to the majoritarian model and its associated values. This is reflected in former president Jimmy Carter's statement in early October 2004 that the presidential campaign was becoming 'too partisan'. The mere fact that one could describe electoral partisanship as a bad thing is illustrative of the increasing acceptance of the model of consensus democracy.

The purported core value of the consensus model is, as the name implies, reaching decisions that are acceptable to the vast majority of the citizens - ideally, all of them - as opposed to decisions that are desired by a majority and imposed on the minority. Institutionally, this means division and the separation of powers, oversized or minority cabinets, and strong and independent courts and central banks - in other words, many veto players and many impediments to the straightforward 
imposition by the winner of a single general election of its/his/her will in public policy. In addition the consensus model is based on decisions delegated to experts and justified with reference to professional norms. When it comes to evaluating the majoritarian and consensus models, it becomes apparent that the standards for consensus democracy are effectiveness and efficiency, proximity of government policy to the policy preference of the median voter, with both winners and losers more or less equally satisfied with the election results.

This emphasis on efficiency in achieving ends that are exogenously defined as good, rather than having been identified as good through the electoral process, has implications for partisan participation that have already been discussed. The implications of the ideal of supersized majorities, multiplication of veto points, proximity of policy to the electoral median, and uniform levels of satisfaction are potentially even more devastating. The first two mean that elections do not determine outcomes; the third implies that policy is unlikely to change much regardless of who wins; and the last implies that the difference in utility between being a winner or a loser (for voters, if not necessarily for politicians) is minimal. Under those circumstances, why would anyone do other than follow Yeats' injunction in his poem 'The Old Stone Cross' to 'stay at home and drink your beer, and let the neighbors vote'?

The final explanation is the general acceptance of neo-liberalism as the dominant economic paradigm. This implies that any government must bow to the market rather than attempt to control it. In particular, it means a commitment to limiting the scope of government regulation and a commitment not to use fiscal or monetary policy instruments for political ends. But this means lowering the stakes of partisan politics by taking what have been traditionally some of the most important concerns of voters - unemployment and inflation - outside the realm in which parties and elections are expected to make a difference. The end effect must again be lower public involvement in partisan politics - or at least in the politics of the mainstream parties.

Returning to the original questions about representation and principal-agent models, I wish to conclude with a few brief observations. All 
the trends which have been discussed mean that the electoral connection of the parties-as-agents-voters-as-principals model is being undercut. There is less electoral participation in the first place, and it is decreasingly motivated as the parties-as-agents-voters-as-principals model requires.

Consensus democracy and neo-liberal paradigms not only lead to an expectation of less public involvement in party politics, they also undercut the idea of a representative as a delegate. In fact, as was said at the outset, there appears to be a striking similarity between representation as I submit it must be understood it in the consensus democracy model and (although I have not directly discussed the cartel party idea in this article) representation as we would understand it within the cartel party model: a shrinking of the policy differences among potentially governing parties; a blurring of distinctions between winners and losers; a lack of popular directive power over parties in public office; and a shedding of responsibility on the part of elected representatives.

All this appears to lead to a model of representation that is highly truncated and that might perhaps be described as a throwback to a predemocratic era in which the king was assumed to be the trustee of the nation, and representatives in parliament might express the concerns or grievances of their constituents, but did not exercise real decision-making power. The objective of government on behalf of the people still remains, but without the effective ability of the people to either decide for themselves what that means, or to reward and punish those who claim to be acting as their trustee(s). This similarity is particularly striking given that the emergence of a cartel party system is generally seen as a danger to democratic government, while the model of consensus democracy often is advanced as a goal toward which democracies should be encouraged to move.

To put this another way, the consensus democracy model and the cartel party model may be essentially the positive and the negative portrayals of the same set of phenomena. From the consensus democracy perspective, we have responsible leadership constrained by reality; from 
the cartel party perspective, we have collusion to avoid raising issues that may be important to the public, but which the elite do not want to see raised in order to avoid responsibility for the unpopularity of policies dictated by what is sold as reality, but may instead be the result of a Gramscian hegemony that defines apparent reality. From the consensus democracy perspective, we have public subsidies of parties as a way to limit the power of special interests and assure a level playing field as between those who are temporarily in office and those who are temporarily out of office; while from the cartel party perspective we have collusion by leaders across party lines to 'feed at the public trough' and to protect themselves, both organizationally and personally, from the costs of popular dissatisfaction. From either perspective we have a vision of government for people who say they love democracy but hate politics.

\section{References}

Blyth, M. and Katz, R.S. (2005). From Catch-All Politics to Cartelisation. West European Politics 28 (January), pp. 33-60.

Butler, D. and Stokes, D. (1969). Political Change in Britain. New York: St. Martin's Press.

Crossman, R. (1976). Diaries of a Cabinet Minister. New York: Holt, Rinehart and Winston.

Dahl, R.A. (1956). A Preface to Democratic Theory. Chicago: University of Chicago Press.

Dahl, R.A. (1961). Who Governs? Democracy and Power in an American City. New Haven: Yale University Press.

Downs, A. (1957). An Economic Theory of Democracy. New York: Harper.

Finer, S.E. (1970). Comparative Government. Harmondsworth: Penguin Books.

Lynn, J. and Jay, A. (1988). Yes, Prime Minister: The Diaries of the Right Hon. James Hacker. Topsfield, MA: Salem House.

Katz, R.S. (2013). Should We Believe that Improved Intra-Party Democracy Would Arrest Party Decline? In: W. Cross and R. S. Katz, eds., The Challenges of Intraparty Democracy. Oxford: Oxford University Press, pp. 49-64. 
Katz, R. S. and Mair, P. (1995). Changing Models of Party Organization and Party Democracy: The Emergence of the Cartel Party. Party Politics 1:1, pp. 5-28.

Kirchheimer, O. (1966). The Transformation of the Western European Party Systems. In: J. La Palombara and M. Weiner, eds., Political Parties and Political Development. Princeton, NJ: Princeton University Press, pp. 177-200.

Lijphart, A. (1999). Patterns of Democracy: Government Forms and Performance in Thirty-Six Counties. New Haven, CT: Yale University Press.

OSCE/ODIHR (2011). Guidelines on Political Party Regulation. Warsaw: OSCE/ODIHR.

Panebianco, A. (1988). Political Parties: Organization and Power. Cambridge: Cambridge University Press.

Parisi, A. and Pasquino, G. (1979). Changes in Italian Electoral Behavior: The Relationships between Parties and Voters. West European Politics 2, pp. 6-30.

Schmitter, P. (2001). Parties Are Not What They Once Were. In: L. Diamond and R. Gunther, eds., Political Parties and Democracy. Baltimore, MD: The Johns Hopkins University Press, pp. 67-89.

Truman, D. (1951). The Governmental Process: Political Interests and Public Opinion. New York: Alfred A. Knopf.

Whiteley, P. et al. (2001). Turnout. Parliamentary Affairs, 54(4), pp. 775-88.

Wibberly, L. (1955). The Mouse that Roared. Boston: Little, Brown.

Richard S. Katz is Professor of Political Science at The Johns Hopkins University in Baltimore. He was co-editor of the European Journal of Political Research (2006-2012), and treasurer (2012-2018) and vice-chair (2015-2018) of the European Consortium for Political Research. His books include $A$ Theory of Parties and Electoral Systems (Johns Hopkins University Press, 1980, 2006), Democracy and Elections (Oxford University Press, 1997), Handbook of Party Politics, ed. with William Crotty (Sage, 2006), The Challenges of Intra-Party Democracy, ed. with William P. Cross (Oxford University Press, 2013).

\section{Richard S. Katz}

The Johns Hopkins University

Department of Political Science

338 Mergenthaler Hall, 3400 N. Charles Street, Baltimore, MD 21218, United States

e-mail: richard.katz@jhu.edu 